\title{
RNF146 wt Allele
}

National Cancer Institute

\section{Source}

National Cancer Institute. RNF146 wt Allele. NCI Thesaurus. Code C99466.

Human RNF146 wild-type allele is located within 6q22.1-q22.33 and is approximately 22

$\mathrm{kb}$ in length. This allele, which encodes E3 ubiquitin-protein lig ase RNF146 protein, is involved in the modulation of poly-ADP-ribosylated protein degradation. 